$\triangle C T A$ NEOPHILOLOGICA

DOI: 10.4312/an.48.1-2.49-66

UDK: 821.411.21'06(620).09Mahfouz N.

\title{
Narrating the Marginalized Oriental Female: Silencing the Colonized Subaltern
}

\section{Saddik Gohar}

\begin{abstract}
A scrutinized reading of the early fiction of Naguib Mahfouz, particularly his masterpiece Midaq Alley, reveals that the author's outward tendency to offer what seems to be a neutral presentation of Egyptian-Arab women is thwarted by a hegemonic master narrative originated in local patriarchal traditions. It either marginalizes the female subaltern downsizing her role in the fictional canvas or conflates her with a status of gender inferiority by assigning her a role which conforms to her image in the patriarchal taxonomy of Oriental women. In other words, the authorial attempt to create an objective narrative of the male/ female controversy in Midaq Alley is totally undermined by a plethora of male voices dominating the fictional text and deploying patriarchal discourses about the depravity of the female race and the invalidity of women's struggle for independence. In this context, the paper argues that due to a hegemonic narrative mechanism, Mahfouz's representation of the female protagonist conforms to domestic patriarchal visions of femininity while on the surface it masks itself as a progressive image of womanhood.
\end{abstract}

Key words: colonization, patriarchy, hegemony, subaltern discourse 


\section{INTRODUCTION}

In one of the early pioneering studies on Naguib Mahfouz ${ }^{1}$, Sasson Somekh points out that women in Midaq Alley ${ }^{2 "}$ are not a complementary element; often they are in the very center of action. Hamida is possibly more prominent than any of the other people presented in the novel" (79). In reality, the reader did not see many events in the novel to verify this assumption. In his delineation of Hamida, the protagonist, the author incorporates a narrative strategy that unconsciously betrays the masculine psyche of a supposedly well-intentioned male Arab writer who attempts to write on behalf of the oppressed and the marginalized female community in his country. Hamida's narrative voice was submerged in a text predominated by a plethora of male voices reflecting the attitude of the imperial narrator. In other words, Mahfouz develops a narrative strategy through which the female is either pushed to the periphery or assigned a status of inferiority or silence.

Moreover, the dehumanizing process which targets the marginalized Oriental female in addition to the absence of a moderate male voice to represent a counter attitude toward the central anti-feminist perspective reinforces the biased discourse of Mahfouz's master narrative controlled by a patriarchal imperial voice. Due to the hegemonic structure of Mahfouz's master narrative, the male / female issue is unfortunately viewed from the viewpoint of the hegemonic patriarchal side. The narrative structure of the novel conspicuously uncovers a camouflaged patriarchal ideology infiltrating the text as a subterranean current. It is noteworthy to illustrate that the narrative strategy of Midaq Alley ${ }^{3}$ is shaped by the author's biased perspective on the male / female equation, which turns the novel into what Jean-François Lyotard calls "grand narrative"( 23).

1 Naguib Mahfouz is (1911-2006), the famous Egyptian writer, is the most celebrated novelist in the Arab world in the twentieth century. He published 34 novels, 350 short stories, five plays and dozens of film scripts. His novels have been transformed into Egyptian and foreign movies. He is the only Arab writer who obtained the Nobel Prize in literature in 1988. Most of his works were translated into more than ten languages and his novels have been taught in universities and colleges worldwide.

2 According to Mona Amyuni, the Arabic name "Midaq" literally signifies a place which indifferently grinds down its dwellers devastating them. The characters are part of the lower strata of the Cairo society. Beneath the surface lurk conflicting evil forces tearing the lives of the alley's inhabitants apart. See Mona Takieddine Amyuni. "Images of Arab Women in Midaq Alley by Naguib Mahfouz and Season of Migration to the North by Tayeb Saleh". International Journal of Middle East Studies 17(1985): 25-36.

3 The events take place in an alley located in a poverty stricken district of Cairo. Its people take the opportunity offered by the WWII to salvage their life from degraded economic conditions. "The conception of the alley as a crucible is carried out with much consistency saving the story from fragmentation." (Somekh 1973: 92). For further details, see Sasson Somekh. The Changing Rhythm: A Study of Najuib Mahfuz's Novels. Leiden: E.J. Brill, 1973. 
In the novel, the voices of the male and female characters are blended into a monologic and imperial voice crystalizing the author's attitude toward the female protagonist. In short, the incidents of the novel are orchestrated by a narrative structure that manipulates the voices of all characters in order to amplify the patriarchal ideology of the author overwhelming the reader with perverted images about Hamida and the female race. The novelist aims to reconstruct reality and obscure the hegemonic policies of patriarchy employing a narrative dynamic through which all the characters turn into mouthpieces expressing his own perspective. By using a narrator who views the female protagonist as a whore by nature, the author attempts to mystify the brutal process of patriarchal subjugation by making it seem to be the inevitable result of female degradation and moral corruption. The hostile treatment of the fallen woman figure, Hamida, in Midaq Alley, subverts critical allegations about what is called "Mahfouz's pro-feminist tendencies". For example, Miriam Cooke points out that prostitutes are "the most interesting and creative women characters" (111) in Mahfouz's fiction. This perspective is not supported by Simone de Beauvoir who argues that "prostitutes as literary figures used as projections of male fantasies" (157).

Combined with the technique of one-sided dialogue utilized in the novel, Mahfouz's narrative strategy aims to distort reality subverting women's images. Instead of defending the female subaltern against the tyrannical practices of a patriarchal culture, the narrator condemned Hamida and punished Abbas, the humble male who failed to subjugate her. By delineating the marginalized female as despicable in her character and totally blameworthy for the suffering of Abbas, the author negotiates the possibility of her removal from the alley. Throughout the text, the author attempts to degrade the female subaltern categorizing her as a whore to justify her subsequent punishment. Furthermore, the destruction of the humanity of the female other is achieved in different ways in the novel either by downsizing her voice or by assigning her roles which confirm to her stereotyped image in local culture or by conflating her with a degraded status reflecting her position in domestic patriarchal taxonomy.

In Midaq Alley the process of marginalizing, subjugating and silencing carries within itself specific gender and class implications. Within the intersection of gender, power and class, silencing is intrinsically related to the precarious situation of the woman as a non-hegemonic object who is either denied the possibility of self-articulation or whose voice is purposefully ignored. In the novel the voice of Hamida is subdued and colonized by a phallogocentric narrator. Besides, the incidents of the novel are monopolized by a narrative mechanism and a hegemonic discourse which confine the marginalized female Oriental to the social ghetto of the harem. Instead of deploying a plethora of voices as reflections of male and female attitudes toward male/female issues, the omnipresent author introduces a 
biased hegemonic voice replacing the discourse of the feminine with that of the masculine in order to make the latter desirable and render the patriarchal narrative consumable.

There is no doubt that Mahfouz's fiction is explicitly dictated by an imperial narrative and the tale is narrated by a male voice whereas Hamida is introduced as personification of evil and sin. As a sexual monster, she is humiliated by being transformed into a whore. When Hamida, the female subaltern, is allowed to speak, her utterances conform to her stereotyped image in local patriarchal iconographies. In addition to the narrow space given to the female protagonist in the textual canvas, the ultimate fictional discourse reveals the existence of gender demarcations separating between male and female. As a reproduction of discourses advocated by patriarchal powers in a conservative society, Mahfouz's narrative reinforces local stereotypes about women rampant in the Egyptian and Arab societies.

\section{SUFFOCATING THE VOICE OF THE VOICELESS}

Though Hamida is the protagonist of the novel, she was not given a substantial space in the narrative canvas. Even in episodes in which she was given focus, the readers see her through the spectacles of the male imperial narrator embodying the voice of the author or via the eyes of the male characters in the novel. The novel consists of thirty five parts mostly devoted to events and motifs integral to the superstitious, corrupt and rapacious community of the alley. Priority is given to narratives engaging male characters such as the wisdom of Mr. Radwan Alhussainy, a landlord in the alley, the drug addiction and homosexuality of Mr. Kirsha, the coffee shop owner, the moral corruption of Mr. Zeta, the cripple-maker, the personal life of Salim Alwan, the rich businessman, the suspicious, illegal activities of Dr. Booshy, grave-digger, the close relationship between Uncle Kamil, the shop owner and Mr. Abbas Alhilu, the barber, the routine work of Mr. Sonkor, the coffee boy, the work of Mr. Hussain Kirsha in the British camp and the connection between the Jewish broker and Salim Alwan, The miserable life of Sheikh Darwish, a government employee who lost his job in the Ministry of Endowment as well as the unfortunate destiny of the local folklore ballads singer abandoned by his audience after the introduction of the radio are also given some narrative space.

Moreover, rumors surrounding old women in the alley such as Umm Hamida, the match-maker and Mrs. Saniya Afifi, the rich widow who aspires to marry a young man are spotlighted in the narrative. The recurrent quarrels between Husniya, the female baker and her husband, Jaada besides the ferocious 
conflict between Mrs. Kirsha and her husband over the issues of homosexuality and drug additions are intermittently emphasized in the mainstream narrative. Minor motifs are also given increasing attention such as the recurrent news about the Second World War, the cooperation between the Egyptian government and the British forces besides episodes dedicated to political corruption and election campaigns. The narrative also includes details regarding the daily activities of the poor female workers from nearby urban quarters who made use of the work opportunities provided by WWII and got jobs in a Cairo factory. Other references are frequently made to the Jewish ghetto girls who are envied for their fashionable appearance and the freedom they enjoyed.

The first part introduces the readers to the male characters in the novel particularly, Radwan Alhussainy, one of the landlords in the alley whereas the second part is dominated by the presence of old sterile women such as Umm Hamida, the lady who adopts the protagonist since her childhood after the untimely death of her mother and Saniya Afify, the wealthy widow and owner of a house in the alley. Hamida, the protagonist appears for the first time in a brief episode in part three and she is seen through the eyes of the imperial male narrator who personifies the voice of the aurhor: "Hamida was in her twenties. Her skin was bronze-colored. Her most remarkable features were her black, beautiful eyes"(Mahfouz, 21) ${ }^{4}$ and sexy body. According to the narrative, the ambitions of the rebellious girl has transcended the boundaries of the alley: "Oh what shame, Hamida. What are you doing living in this alley? She felt jealous of the girls who work in the factories, those Jewish girls who go to work. They all go about in nice clothes" (24). Hamida wants to emulate the factory girls but she is aware of her limitations. She does not have a certificate or school education to follow on their heels. She felt jealous of the Jewish girls from the neighborhood, but she hates the factory girls descending from slums and poor districts in Cairo who succeeded in getting jobs and became economically independent.

Hamida resented them for their prosperity and freedom: "They imitated the Jewish girls by paying attention to their appearance and in keeping slim. Some even used unaccustomed language and did not hesitate to walk arm-in-arm and stroll about streets of illicit love" (35). Moreover, in part five, Hamida encountered Abbas, the young barber who expressed his love for her: "She saw the sparks of love in his eyes just as she suspected it was there when he stared at her window. She knew his financial state was not impressive but his personality was submissive and humble. This should have pleased her dominating nature" (37). Because of her attitude to dominate, Hamida violates the roles implemented by the surrounding

4 All subsequent citations from the novel will be taken from Naguib Mafouz, Midaq Alley, Trans. Trevor Le Gassick. Washington, D.C.: Three Continents Press, 1977. 
patriarchal society, thus she must be punished. Abbas also must be punished because he surrendered to Hamida, a woman who turns him into a puppet in her hand. This act is a violation of the domestic masculine conventions integral to Arab manhood. In addition to her feminine skills "in attracting men", she yearns for power and "love for money" (34). According to the narrator, Hamida is haunted by "a desire to fight and conquer men", therefore she is ostracized and outraged by the male community.

In part ten, Hamida met Abbas briefly for the second time and he proposed to her. He told her that he decided to work for the British army in order to make a fortune and make her happy. He plans to visit their house and publically proposes to her: "I will meet your mother. The arrangement must be made before I leave"(76).

Furthermore, in part thirteen, the engagement rituals were consummated and Hamida had the first emotional /semi- physical contact with Abbas on the dark stairs in her house at the night prior to his departure: "He took her arm and drew himself gently towards her. His mouth searched desperately for hers, touching first her nose and then making its way down to her lips which were already parted in welcome. He was transported on a wave of ecstasy from which he did not recover until she gently drew herself from his arms and went upstairs" (94). Hamida enjoys her first romantic experience with Abbas undermining authorial allegations about her tough and unfeminine nature: "Hamida had never before had such an emotional experience. For this one brief period in her life, she brimmed with emotion and affection, feeling that her life was forever bound to him" (93).

In part eight, Hamida is captured through the eyes of Salim Alwan who wants to remarry because his first wife was not able anymore to gratify his sexual instinct. Once he caught a glimpse of Hamida, he told himself: "Yes, she was indeed poor and lowly, but unfortunately desire could not be denied, could it? She was poor and humble, but what about her bronze-colored face, the look in her eyes and her lovely slender body?" (59). Afterwards, Hamida appears briefly expressing her desire to accept Salim Alwan's marriage proposal after he talked with her foster mother. In this context, she is presented through the eyes of the narrator as a diabolical cunning girl. After the proposal of the Alwan, the company owner, she repudiates her commitment to Abbas without any qualms. She forgot the emotional experience she had with him on the staircase on the eve of his departure when she thought she was forever bound to him. When Alwan asked her hand in marriage, Hamida discarded her first fiancé with no regrets because he had really been banished from her heart long time after his departure. She also rejected the advice of Mr. Alhussainy who told her mother to turn down the marriage proposal because "The barber is young and Mr. Radwan is old; the barber is of the same class as Hamida and Mr. Radwan is not" (124). Hamida's ambitions to break the social taboos and transgress the class structure in the alley are not permitted in 
Mahfouz's world and therefore her marriage from Radwan should not be consummated. Eventually, Radwan fell ill due to a sudden heart attack which terminated his sexual potency forever. The news of Radwan's sickness struck Hamida "like a thunderbolt" (126).

In part twenty, Hamida met with the pimp, Ebrahim Farag for the first time. As a supporter of one of the corrupt politicians, Farag infiltrated into the alley during general elections campaigns. Hamida believed he fell in love with her like others and was intoxicated by his warm words: "This is not your quarter, nor are these people relatives of yours. You are completely different. You do not belong here at all. How can you live among these people? Who are they compared to you? You are a princess in a shabby cloak" (143). Before she fell into the snares of Farag who will unmask his real identity as a pimp "a tiger waiting for an opportunity to leap", she was momentarily engaged in a love affair with him because he mastered the role of the passionate lover. Besides, in part twenty two, the third person narrator views Hamida very briefly. Her image is projected through the eyes of Salim Alwan who survived the heart attack but remained impotent. He recalls his desire for her when Umm Hamida visited him after he returned to the alley: "Was it not strange how he had forgotten Hamida as though she had never existed? It was as though she had been a small drop of the healthy blood that flowed in his veins and when his health had gone she had vanished with it" (153).

In part twenty-three, Hamida fell in the trap of the pimp and decided to elope with him and leave the alley. Farag recruits whores to entertain the British soldiers in Cairo during the time of WWII. Consequently, he takes Hamida to a building in downtown Cairo where he teaches his female victims how to become professional prostitutes after training them to master Oriental and Western dancing in addition to the English language. When she discovered the reality of Farag she did not quit. She told him "you are trying to corrupt me. What an evil, wicked seducer you are? You are not a man, you are a pimp" (168). He told her that he is a pimp and "the headmaster of a school" (178). Though aware of Farag's evil intentions, Hamida accepted prostitution willingly and became an accomplished whore in a short time. Farag is fully aware that Hamida will not leave him simply because "she is a whore by instinct" (170).

In part twenty five and as a result of her disappearance, Hamida becomes the talk of the alley. Hussain Kirsha told his mother: "She has run away. Someone has seduced her, taken position of her senses and run off with her" (185). Moreover, the protagonist's name is changed into Titi to fit her new role as a prostitute serving British soldiers who found it more difficult to pronounce her original name "Hamida". In Farag's prostitution house, she met with met with the English language teacher and the effeminate dancing teacher Susu who is a kind of lady boy. In part twenty-six and for the first time in her life, Hamida had a full sexual 
relation surrendering her body to Farag. While in bed and just before penetrating her virginity, Farag refrained from completing the sex act and behaved as a pimp. He withdrew and said: "Gently, gently, American officers will gladly pay fifty pounds for virgins" (192). In response "she sat upright on the bed, then sprang to the floor with amazing speed like an enraged tigress. Now all her vicious instincts were roused as she slapped his face with such a force that the blow crackled through the room." In retaliation, "he struck her right cheek as hard as he could. Then he slapped her left cheek just as violently. She clung to him, her head raised towards his face, her mouth was trembling with passion"( 193).

In part twenty eight, Abbas returned home to discover the scandal of Hamida's escape from the alley. In his search for her, he encountered the factory girls who told him that they "saw her several times with a well-dressed man in suit" (204). Throughout part thirty, Abbas was searching for Hamida in the taverns of Cairo and in Vita's Bar in the Jewish Quarter in the city. In part thirty-one, Hamida is disappointed after Farag informs her that he is not a marrying man. He told her in a sarcastic tone "Tell me my darling, are people still getting married?" (223). At this point, she was not able to go back to the alley or Abbas. She reached a point of no return as she was fully transformed into a professional prostitute: "She had now learned Oriental and Western dancing and she also showed a quicker ear for learning the sexual principles of the English Language" (219). When she encountered Abbas in part thirty-two, she cunningly moved him against Farag in order to get rid of both males ${ }^{5}$ according to critical allegations. During the meeting Abbas was enraged and in his fury he swore to kill the pimp who destroyed their life.

Subsequently, he orchestrated a plan in collaboration with his friend Hussain Kirsha to punish the seducer. Instead of avenging himself on the pimp, Abbas attacked Hamida with a broken bottle paving the way for his murder at the hands of the British soldiers. In part thirty-four, Abbas glimpsed Hamida entertaining British soldiers in a tavern. In the frenzy of his anger, he forgot the pimp and rushed towards her striking her with a bottle smashing her face : „He saw Hamida sitting amidst a crowd of soldiers. One stood behind her pouring wine into a glass in her hand, leaning towards her slightly as she turned her head towards him. Her legs were stretched on the lab of another soldier sitting opposite her and there were others in uniform crowding around her, drinking boisterously" (241).

In the presence of Hussain and other passers-by, Hamida was severely injured but survived the quarrel. The narrator describes the scene as follows: "blood poured in a stream from her nose, mouth and chin mixing with the creams and powers on

5 For more details on this perspective, see Marius Deeb. "Maguib Mahfouz's Midaq Alley: A Socio-Cultural Analysis" in Critical Perspectives on Naguib Mahfouz, Edited by Trevor Le Gassick. Washington, DC: Three Continents Press, 1991, pp. 27-36. 
her face and running down on to her neck and dress" (241). Noticeably, the drunk British troops killed Abbas in retaliation after Hamida's screams drove them crazy. Many angry and powerful soldiers fell on Abbas from all sides like wild animals crushing him to death. At the end of the novel part thirty-five the alley was informed by Hussain of the details pertaining to the death of Abbas and the injury of Hamida. Eventually, the alley restores its old way of life as if nothing happen: "The alley returns to its usual state of indifference and forgetfulness" (244).

\section{CONSTRUCTING A PATRIARCHAL PATTERN}

In addition to patriarchal hegemony, the narrative undeniably betrays trajectories of power structure crucial to the sexual relations and the image of women in Midaq Alley. The theme of British colonization infiltrates into the text with details regarding the WWII era, where downtown Cairo was the sanctuary of prostitution houses and taverns originally erected to entertain the foreign soldiers situated in military camps encompassing the capital city. Hamida was trained as a prostitute to serve in these brothels, however she was mainly victimized by what Kate Millett refers to as "interior colonization" (cited in Amyuni, 25). Moreover, Hussain, representing the Egyptian masses, was an eye-witness to the murder of Abbas, the innocent young man and the sexual violation of Hamida (Egypt). In this context, Hamida may figuratively epitomize Egypt who is viewed as a prostitute exploited by a corrupt political regime who gave her to the colonizers.

In a related context, Mona Mikhail sees Hamida as a fallen virtuous woman and a victim (76) whereas Marius Deeb argues that the protagonist is an ambitious social climber and a cunning woman who "wants to be liberated from Farag both emotionally and economically and hopes that after a violent encounter between Abbas and Farag, both will end up in prison or perhaps perish and thus she will regain her freedom and continue to pursue her career" (33). Regardless of the preceding critical arguments, the narrative unveils a battered image of the female protagonist. Throughout the narrative, Hamida is demonized by the narrator who weaves an entangling web of myths around her immersing her into a state of irredeemable immorality. The novel is overshadowed by gendered power structures and patriarchal discourses and sexist depictions of the female other. In like manner, the protagonist is stigmatized by being presented as a prostitute who denounced the traditional roles of a wife and mother. She has a negative impact on her male lovers. Abbas is emasculated, demeaned and became effeminate due to Hamida's spells over him. Hamida is penalized because she ferociously fights against domestication and refused to envision the world from a patriarchal angle. Indisputably, the fictionalized Oriental protagonist in 
Mahfouz's novel is viewed as being naturally subservient to a superior and morally mature power.

In Midaq Alley, patriarchal subjugation of women is triggered by its alleged adherence to idealized traditions of wifehood and motherhood. The incidents in the novel, which are reproduction of domestic patriarchal narratives, aim to disempower and Orientalize the femininity potential. Since Orientalizing is a basic strategy of marginalization, the female protagonist is transformed into a cultural object, Orientalized and marginalized to conform to her image in patriarchal categorization of women. Historically, the destruction of female images is a recurrent, almost a ritualistic practice in fictional discourses by male Arab writers, therefore the female subaltern, in Mahfouz's novel, is either denied a voice or appears in the single image of a decadent whore. Simone de Beauvoir observes that prostitutes "as literary figures are used as projections of male fantasies" (157). On this basis, the poor female other in Midaq Alley is fictionally exploited cope up with the anti-feminist discourses integral to contemporary Arab culture.

Surprisingly, Cooke refers to what she calls "a narrative voice" allegedly given by Mahfouz to his female characters, thus she identifies him as a feminist novelist (108). However, Midaq Alley is abounded by a narrative praxis which uncovers the author's commitment to a patriarchal ideology manifesting itself in the tenor and texture of the text. The act of narration accommodates thematic concerns and other related issues - deeply entrenched in the author's gender and religious/ cultural orientation - which intrude on the text subordinating the narrative to the prejudice and subjectivity of the male novelist or what Monika Fludernik calls "the repurposing of narrative techniques" integral to some texts (784). The omnipresent author employs a highly subjective male perspective expressed through a hegemonic authorial narrative strategy and a language (verbal violence) condemnatory of women.

The narrative of Midaq Alley is overwhelmingly masculine and the voice of Hamida is smothered in the text. Even in the few episodes dominated by her presence, the readers see her throughout the male perspective of the third person narrator. The image of Hamida as a strong woman with sharp tongue conforms to a deeply rooted stereotypical notion of feminine cunningness inherent in Arab cultural mythology and religious traditions. According to the narrator, Hamida overtly epitomizes non-maternal womanhood. She hates children and does not want to be a mother in addition to her disposition to deceive others. In Mahfouz's narrative, Hamida is delineated physically to unearth nothing except her beauty,

$6 \quad$ For more details on narratology and narrative theory, see Monika. Fludernik. 1998. Encyclopedia of the Novel (V.2), edited by Paul Schellinger, Christopher Hudson, and Marijke Rijsberman. Chicago: Fitzroy Dearbon Publishers, 1998, pp. 784-801. 
seduction and sensuality. In reality, Hamida represents the downtrodden and the pariahs of the Cairo lower class. Her inner turmoil and psychological problems resulting from her poverty and inferior status are completely invisible in the text.

Portraying Hamdia's conflict with society from a masculine viewpoint and taking over the typology intrinsic to Arab culture of degraded women confronting conservative traditions, the narrative discourse of Mahfouz's novel categorizes the female as inferior and demonic. Unfortunately, the invisibility of a respectable female voice in the novel provides an impetus to the distorted male discourse of the text assigning the female a role which conforms to her degraded image in local culture. Moreover, the frequent appearance of the female victim in the speeches of hegemonic male narrators problematizes the narrative interfaces of the novel. Instead of viewing the female from a balanced perspective, Mahfouz's master narrative, overshadowed by an anti-feminist discursive strategy, becomes a reproduction of domestic patriarchal stereotypes about women inferiority strengthening the boundaries of racial and gender differences between men and women. Further, the dispersion of a militant patriarchal version of womanhood in the text transforms Midaq Alley into a masculine narrative neglecting the rights of the oppressed females.

For example, the hopeless condition of Hamida as a down-trodden orphan afflicted with abject poverty is completely ignored in the novel. Instead, she is introduced, throughout the narrative, as a sexual object to be penetrated. She was given three difficult options: poverty affiliated with marriage from Abbas, the barber or subjugation associated with selling her body in a business marriage from Salim Alwan or prostitution. As a tragic character she has to choose between the home or the brothel. Here lies the narrator's complicity with the values of a patriarchal society and the stereotypical fears about the catastrophic consequences of female sexuality are consequently emphasized. Moreover, Hamida's sexuality jeopardizes the alley's male moral values, therefore she is forced to project her sexuality outside the alley in prostitution houses. Hamida is also oppressed because she turned down the advice of Mr. AlHussany, a symbol of patriarchy in the alley, regarding her marriage from Salim Alwan. In short, she is banished from the alley because she dares to rebel against patriarchy, male supremacy, the pressures of poverty, traditional marriage and social classification.

In Midaq Alley, the author utilizes several narrative subtleties which aim to silence the voice of Hamida and re-inscribe negative stereotypes about her and the female community in the alley. Such stereotypes contribute to a discursive strategy which aims to locate or fix the female other in a position of inferiority. Through presentations of reveling descriptions - appropriated by the male narrator - of Hamida where scenes of lust and elaborate accounts of sexual desire prevail, the author attempts to reconstruct an imaginary voluptuous female who 
fits the morbid attitudes of a patriarchal society toward women. This stereotyping process requires the aesthetic function of stimulating and tantalizing the reader's fantasy with passages about female sexual corruption. After being exhibited to the readers, the female stereotype has to conform to local customs: she should be a replica of Satan, an incarnation of evil. In Midaq Alley, Hamida is demonized by the male narrator who portrays her as a fallen woman from the beginning of the novel. Even Abbas the only person who sympathizes with Hamida was unjustly punished for lack of masculinity because he sympathized with her considering her a victim of Farag, the pimp rather than a promiscuous sinner. Ironically, the pimp survives and continues his career bringing more females to the prostitution trade serving the foreign soldiers.

In Mahfouz's fiction, the relationship between men and women is one of power and domination where the imperial male voice makes use of imaginative speculations to produce erroneous stereotypes of the female subaltern. The author assigned the central roles, in his novel, to male characters while the Oriental female is either subjugated or marginalized. Unequivocally, most of the narrative of Midaq Alley is controlled by masculine voices which, from the perspective of a neutral reader, are not justified in their dehumanization of the female other. In the same vein, the monolithic narrative strategy latent in Mahfouz's fiction is not justified in marginalizing the Oriental female as second class citizen or essentializing her as an inheritor of a degraded sexual impulse threatening the moral codes of a conservative society.

There is no doubt that the events of the novel bear testimony to the marginalized position of Hamida. She is explicitly persecuted because she strives for her emancipation. She is subordinated by phallocentric culture depriving her of education and a respectable career. Hamida is obviously a victim of a racist patriarchal ideology which aims to humiliate and suppress the female subaltern in order to tyrannize her. Mahfouz failed to view Hamida as the voiceless victim of ever-deepening oppression and poverty entrenched in layers of male supremacist tradition. He was also reluctant to condemn an obnoxious culture that suffocated women obliterating their humanity. Ironically Hamida's voice is released in marginal episodes whereas the voice of the male narrator occupies central ground in the narrative. This act on the part of the author/narrator reflects the commodification and the demeaning stereotyping of the female protagonist.

By narrowing the feminist viewpoint, in Midaq Alley, Mahfouz attempts to marginalize the female subaltern restricting the space in which she can be re-written back into social history. In a novel shaped by authorial pro-patriarchal inclinations, the female protagonist is introduced in a way that fulfills patriarchal authorial agendas. She appears without form until she is reconstructed by the masculine narrator. In Midaq Alley, there is no space from where the subaltern subject can 
speak because her voice is muted by the male author. Deploying a narrative dynamic through which Hamida is allowed only to utter statements which reveal a tendency toward debauchery and desire for wealth, the author aims to acquit the male community from any accusation of hegemony and brutality.

From the beginning of the novel, Hamida is described by the narrator as an aggressive girl who dreams of subjugating men: "She could take on an appearance of strength and determination which was most unfeminine" (21). The narrator criticizes her obsession with dominating and impressing others and her insistence on challenging and defying her society and its moral values. Further, the narrator emphasized that most of the inhabitants are not spared the sting of her tongue. The narrator also told the readers three times that her voice is not pleasant (unfeminine). Even her beautiful eyes framed with kohl reflect her ferocity and determination. In a nutshell, the narrator sets up the norms of femininity as "weakness, passivity and vacillation" (Cooke, 116) adding that "she hated children and that this unnatural trait made her wild and totally lacking in the virtues of femininity" (40). It is well-known that in Arab culture, the "specific trait of nurturing children is apparently an exclusive attribute of the female gender" (Oersen, 54).

By making the whole tale narrated by a pro-patriarchal narrator, the voice of Hamida is either submerged or muted. Further, the distressed Hamida is reduced to an object, a horrible simulacrum of a human being. Due to Mahfouz's narrative strategy which eradicates the identity of Hamida enclosing her into a degraded classification, the pro-feminist counter-narrative is underestimated. As a strategy of presentation rooted in masculine discourse and patriarchal degeneration, Mahfouz's narrative apparatus places the male narrator at the center of the text marginalizing the female voice of Hamida because she debunks the myths of a conservative society. As a lustful monster, Hamida should be humiliated by being transformed into a prostitute selling her body to the British soldiers who represent the colonial forces occupying the land of Egypt.

It is relevant to argue that the male/female controversy in the novel is undermined by a narrative strategy that prioritizes the male patriarch and deprives the feminized Oriental from entering the text except as a non-person or a vicious whore. The marginalized status of the female protagonist and the use of a narrative strategy that advocates the moral perspective of the male narrator leads to the construction of a subterranean anti-feminist motif underpinning the text. Social and sexual issues in addition to the intersection between poverty and prostitution are also depicted from the viewpoint of the dominating male while the vulnerable and destitute female is totally muted and denied a reasonable voice to express her attitude toward a society dehumanizing her for decades.

Using an imperial patriarchal voice to introduce the story of Hamida to local audience and incorporating a narrative strategy which mutes the marginalized 
female so that her voice cannot be heard, the novel produces a prevailing view about women that is totally accepted and endorsed by the local community. In Midaq Alley, the female perspective toward different issues is introduced either by the faint voices of marginalized characters or filtered throughout the eyes of a dominating anti-feminist narrator. Like Orientalists who speak to the West on behalf of backward societies, the central narrator in the novel presents the female subaltern to the Arab reader in a way that conforms to local standards, as vicious and decadent. The process of preventing the female from entering the text except as a decadent inferior Oriental aims to perpetuate racist patriarchal stereotypes and enhance gender division. On the surface, the novel seems to be an attempt to offer a critique of the patriarchal master narrative widely accepted in the Arab world about women, nevertheless, the author fails to provide an alternative to such hegemonic discourse due to a strategy of narration which silenced the marginalized female or periodically removed her out of the text. Categorically, the author places male characters at the center of the text preventing the victimized subaltern from introducing her counter-narrative in an appropriate manner.

\section{CONCLUSION}

In Representing the Colonized, Edward Said refers to the concept of silencing which has been affiliated to women's positions in patriarchal societies in addition to other marginalized groups and minorities: "The colonized has since WWII expanded considerably to include women, subjugated and oppressed classes, national minorities and even marginalized or incorporated academic sub-specialties" (207). As Said puts it "to be one of the colonized is potentially to be a great many different but inferior things, in many different places, at many different times" ${ }^{7}$ What colonized cultures and marginalized groups have in common is their placement in relationship to a dominant culture that impinges upon them and seeks to define and silence them. In hegemonic cultures, there is no possibility for an alternative thinking because one of the most powerful distinctions between the colonizer and the colonized is the emphatic difference between a speaker with agency and the figure of what Gayatri Spivak calls "the silent or the silenced subaltern". ${ }^{8}$

In the early fiction of Mahfouz, such as The Cairo Trilogy, women are mostly portrayed as silenced subalterns who are not allowed to speak all the time. In other words, the female subaltern sometimes speaks but not from a subject position recognized by a patriarchal and sexist culture. In the hegemonic society of Cairo

7 See Edward Said. Representing the Colonized : Anthropology's Interlocutors. Chicago, Illinois: University of Chicago Press, 1989, p. 207. 
reflected in Midaq Alley, the woman is depicted as a subjugated object colonized and appropriated by patriarchal discourse that considers her speech as irrelevant. In the novel, male/female analogy is explored from a purely male-oriented perspective similar to other prejudiced treatments of related topics deeply seated in Arabic literature. As the paper argues, Mahfouz's attempt to introduce a neutralized image of Eastern women reflecting what critics call "his balanced view" toward feminine issues is eclipsed by a biased narrative strategy providing credibility to the patriarchal vision introduced by the male narrator. On the surface, the narrative of Midaq Alley gives a false impression that the author aims to introduce the image of the female from an objective viewpoint different from anti-feminist treatments advocated by other Arab writers. Nevertheless, a thorough reading of the text provides evidence that writing can never be a neutral activity.

The narrative of Midaq Alley is controlled by an omnipresent and omniscient author relying on narration as a substitute for reliable facts operating from a common assumption that both the novelist and the reader shared a stable set of standard convictions which regulated the pattern of their expectations. The events of the novel are in the grip of an infallible and authoritative narrator. This kind of narration is based on a belief in "the infallibility of mimesis" which was seen as a solid representation of life with its verisimilitude as the ultimate proof of its plausibility and relevance to the reader's experience (Hafez, 102). ${ }^{10}$ In the forties when Midaq Alley was written, the main criteria of adequate narrative was plausibility and the ability of the text to consolidate the reader's own experience of reality. The narrative with its trustworthy reproduction of the typology of the alley, the old area in Islamic Cairo, and its social, cultural historical trajectories as valid examples of such approach. This narrative ${ }^{11}$ method involves reproduction of reality in a way that would convince the reader that what he reads has already happened.

The narrative structure possessed by the omniscient novelist is unmistakably contingent upon monophony and a unitary vision. All characters are viewed from the same viewpoint and this unified perspective provides the narrative's cohesion.

$9 \quad$ See Miriam Cooke. "Men Constructed : In the Mirror of Prostitution", In Naguib Mahfouz : From Regional Fame to Global recognition, Edited by Michael Beard and Adnan Haydar. New York: Syracuse University Press, 1993, pp. 106-125.

10 Sabry Hafez illustrates that during the 1940's, the Arab novelist adopted western cultural models of narration exhibiting his control over his narrative world advocating the methods of the natural science as a model for the rationalization of other disciplines. For more information on "the infallibility of mimesis" see Sabry Hafez. "The Transformation of Reality and the Arabic Novel's Aesthetic Response”. Bulletin of the School of Oriental and African Studies Vol. 57 (1994): 93-112.

11 For more information on narrative constructions, see Kenneth Burke. Counter Statement. Berkeley: university of California Press, 1968, pp. 120-123. 
This vision manufactures a simple connected plot whose coherence is essential to syllogistic progression in a causal and chronological manner. The concept of time is that of a logical unfolding of events. This reliance on the causal logic transforms the novel into a closed text as defined by Umberto Eco (3). ${ }^{12}$ In Midaq Alley, Hamida's freedom was defined and constrained by the norms imposed by the omniscient novelist whose omnipresence and imperial control over the narrative are reflections of patriarchal policies and the centrality of authority. The narrative of Midaq Alley focuses on Hamida's rebellion and her career as a whore. It was not concerned with the psychological aspects of Hamida who like most of the women in the same alley was oppressed by men. Like other women, she was "more or less inferior to men on almost all levels, whether economic, social or political". ${ }^{13}$ The women community in the alley is marginalized, subjugated and brutally crushed. According to Ebrahim El-Sheikh, women "were toiling hard to feed their hungry families, while others were denied all chance of a decent life or even the slightest glimpse of hope to improve their lot" (88).

Manifestly, Hamida's fate is determined by forces outside and inside the alley represented by the British soldiers, the pimp and a repressive patriarchal culture. Like Western colonizers exploiting Hamida's body, the local males are not distinguished from the predatory colonial forces occupying the country. In fact, Hamida surrendered to the colonizers because she was initially defeated by the domestic patriarchal power structure she challenged. The defeat of Hamida symbolizes a record of multiple set-backs experienced by Egypt, a country ruled by a puppet government and occupied by invading colonizers. In her search for a mechanism of liberation that stands in marked contrast to the backward masculine traditions of the alley, Hamida confronted a more brutal force that will colonize her body after colonizing the land of her home-country. Unlike other women in the alley who do nothing to change the status quo, Hamida only takes action by willingly becoming a prostitute: "Hamida stoops to prostitution by force of overwhelming circumstances and external factors." (Somekh, 84). She has to break out of a world "that expects her to be other than she wants to be. She will break that particular circle only if she can escape the constrictions of her space" (Cooke, 116). Hamida tries to challenge a merciless society using the only weapon she possesses, her body and herein lies her tragedy.

She is defined by the hegemonic discourse of the text as irredeemably other because she questions the patriarchal system articulating her discontent with

12 For further details, see Umberto Eco. The Role of the Reader: Explorations in the Semiotics of Texts. London : Hutchinson, 1979, pp. 3-43.

13 See Ibrahim El-Sheikh. "Egyptian Women as Portrayed in the Social Novels of Naguib Mahfouz". In Critical Perspectives on Naguib Mahfouz, Ed Trevor Le Gassick. Washington, DC: Three Continents Press, 1991, p. 88. 
the life style in the alley. Hamida poses as a dangerous woman who destabilizes the fixed moral codes of the alley, thereupon she should be intimidated and displaced. Her demands for more freedom fell on deaf ears and she is physically silenced by those who have the power to give her speech vitality. In Midaq Alley, the hegemony of the dominant male culture perpetuated its power through a totalizing discourse which isolates the female protagonist to the historical ghetto of the harem. Instead of confronting the totalizing / silencing discourse of the male mainstream culture, Mahfouz succumbs to domestic patriarchal politics. The text is infiltrated by a masculine authoritative discourse annihilating and negating the identity of the female protagonist who is deemed of rebellion against local moral values.

The minor role given to Hamdia, the protagonist and the limited narrative landscape given to moderate characters such as Uncle Kamil and Sheikh Darwish prioritizes the militant masculine perspective latent in the narrative. By obscuring the female mindset and marginalizing moderate viewpoints toward women, the narrative strategy utilized in Midaq Alley produces a prevailing view of the female subaltern that ignores the victim and advocates the opinion of the hegemonic male community. As a descendant of the Oriental women in the harem, Hamida fails to reformulate an independent personality. Personifying the voices of silenced women, Hamida starts a personal search for a voice, a new identity outside the alley but her desperate attempts collapsed because the patriarchal world offered her three options: to live in poverty with Abbas, the barber or be enslaved by local patriarchy represented by Salim Alwan or become a harlot prostituting her body and entertaining the colonizer.

\section{REFERENCES}

Amyuni, Mona Takieddine. "Images of Arab Women in Midaq Alley by Naguib Mahfouz and Season of Migration to the North by Tayeb Saleh". International Journal of Middle East Studies 17(1985): 25-36.

Cooke, Miriam. "Men Constructed : In the Mirror of Prostitution". In Naguib Mahfouz: From Regional Fame to Global recognition, Edited by Michael Beard and Adnan Haydar, 106-125. New York : Syracuse University Press, 1993.

De Beauvoir, Simone. The Second Sex, trans. H.M. Parshley. New York: Vintage, 1974.

Deeb, Marius. "Maguib Mahfouz's Midaq Alley: A Socio-Cultural Analysis". In Critical Perspectives on Naguib Mahfouz, 27-36, Edited by Trevor Le Gassick. Washington, DC.: Three Continents Press, 1991.

Eco, Umberto. The Role of the Reader : Explorations in the Semiotics of Texts. London: Hutchinson, 1979. 
El-Sheikh, Ibrahim. "Egyptian Women as Portrayed in the Social Novels of Naguib Mahfouz". In Critical Perspectives on Naguib Mahfouz, 85-100, Edited by Trevor Le Gassick. Washington, DC.: Three Continents Press, 1991.

Fludernik, Monika. Encyclopedia of the Novel (V.2), 784- 801. Edited byPaul Schellinger, Christopher Hudson, and Marijke Rijsberman. Chicago : Fitzroy Dearbon Publishers,1998.

Hafez, Sabry. "The Transformation of Reality and the Arabic Novel's Aesthetic Response". Bulletin of the School of Oriental and African Studies 57 (1994): 93112.

Lyotard, Jean-Francois. The Postmodern Condition : A report on Knowledge, Trans. Geoff Bennington and Brian Massumi. Minneapolis: University of Minnesota Press, 1991.

Mafouz, Naguib. Midaq Alley, Trans. Trevor Le Gassick. Washington, D.C.: Three Continents Press, 1977.

Mikhail, Mona. Images of Arab women: Fact and Fiction. Washington, DC.: Three Continents Press, 1978.

Oersen, Sheridene Barbara. The Representation of Women in Four of Naguib Mabfouz's Realist Novels : Palace Walk, Palace of Desire, Sugar Street and Midaq Alley: MA Thesis. University of Western Cape, South Africa. 2005.

Said, Edward. Orientalism. Harmondsworth: Penguin, 1995.

Somekh, Sasson. The Changing Rhythm : A Study of Najuib Mabfuz's Novels. Leiden : E.J. Brill, 1973.

Saddik Gohar

UAE University, Al Ain

s.gohor@uaeu.ac.ae

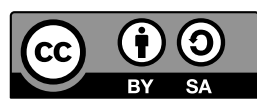

\section{Pripovedi o marginalizirani orientalski podobi ženske: utišanje kolo- niziranega podrejenega}

Natančno branje zgodnje proze Naguiba Mahfouza, še posebej njegova mojstrovina Midaq Alley, odkrije avtorjevo zunanjo tendenco ponuditi karseda nevtralno presentacijo egiptovsko-arabskih žensk. Ta je močno omejena s hegemonsko glavno pripovedjo, ki temelji na lokalnih patriarhalnih tradicijah.

Ključne besede: kolonizacija, patriarhalnost, hegemonija, diskurz podrejenega 